\title{
LABORATORIJSKO ODREĐIVANJE DINAMIČKIH PARAMETARA JEDNOSTAVNE GREDE OMA METODOM
}

\author{
DYNAMIC PARAMETER DETERMINATION ON \\ SIMPLE SUPPORTED BEAM USING OMA
}

\section{Tomislav Franković* , Katarina Paparić*, Ivana Štimac Grandić ${ }^{*}$}

\begin{abstract}
Sažetak
U radu je prikazana provedba dinamičkog ispitivanja čelične grede poprečnog presjeka $30 \times 50 \times 3,2 \mathrm{~mm}$ ukupne duljine 3,0 m s ciljem utvrđivanja njezinih dinamičkih parametara (frekvencija, modalnih oblika $i$ vrijednosti prigušenja) uporabom operativne modalne analize. Glavna prednost operativne modalne analize u odnosu na eksperimentalnu modalnu analizu je mogućnost određivanja modalnih parametara ispitnog objekta bez poznavanja pobude. Pobuda se nanosila u jednoj točki grede, a dinamički odziv grede na nanesenu pobudu mjeren je pomoću jednoosnih akcelerometara osjetljivosti $100 \mathrm{mV} / \mathrm{g}$ čiji je broj i razmještaj variran tijekom provedbe ispitivanja. Prikupljanje izmjerenih podataka i njihova analiza napravljena je pomoću programskog paketa za analizu vibracija ModalVIEW. Pri određenim mjerenjima korištena je mogućnost zadavanja interpolacijskih točaka između mjernih točaka (točke u kojima se nalaze akcelerometri). Analizom odziva grede na pobudu dobivene su frekvencije $f_{i}$, modalni oblici i modalna prigušenja $\xi_{i}$. Ispitivanjem su frekvencije $i$ modalni oblici uspoređeni s frekvencijama $i$ modalnim oblicima izračunatim na numeričkom modelu kojim je uvriježeno modelirati ispitani sustav.
\end{abstract}

Ključne riječi: operativna modalna analiza, modalni oblici, frekvencija, prigušenje

\begin{abstract}
This paper presents dynamic analysis of rectangular hollow section $30 \times 50 \times 3.2 \mathrm{~mm}$ steel beam of $3.0 \mathrm{~m}$ in length with the aim of determining the values of the dynamic parametres (modal frequencies, modes and modal damping) using the method of operational modal analysis. The main advantage of this method in comparison to the experimental modal analysis is the ability of getting modal parameters of a test

\footnotetext{
* Sveučilište u Rijeci, Građevinski fakultet, Radmile Matejčić 3, 51000 Rijeka

E-mail: tomislav.frankovic@gradri.uniri.hr; katarina.paparic@student.uniri.hr; istimac@uniri.hr
} 
object without knowing the excitation. For the validation of experimental results, a numerical model was constructed in STAAD.Pro. The excitation on the test object was made in one specified point, and the dynamic output of the beam was measured using uniaxial accelerometers with sensitivity of $100 \mathrm{mV} / \mathrm{g}$, which were placed in several characteristic points. Data acquisition and their analysis was conducted using vibration analysis software ModalVIEW. In some measurements, the principle of interpolation points between the measured points (points with accelerometers) has been used. Measuring the response to the excitation frequencies $f_{i}$, modes and modal damping $\xi_{i}$ were acquired ( $i=1,2, \ldots, n$ where $n$ represents the number of modes). Frequencies and modes obtained experimentally were compared to the frequencies and modes calculated on a numerical model of the beam.

Key words: operational modal analysis, modes, frequency, damping

\section{Uvod}

Vibracijska analiza različitih konstrukcijskih elemenata temelji se na određivanju njihovih modalnih parametara (modalni oblici, modalne frekvencije i koeficijenti prigušenja). U zadnjih dvadesetak godina značajno se razvila metoda operativne modalne analize (Operational Modal Analysis) kojom se nastoji odrediti gore navedene modalne parametre na temelju odgovora sustava na pobudu. Na Slici 1 dan je shematski prikaz linearnog vremenski nepromjenjivog sustava [1], na čijem se principu temelji operativna modalna analiza.

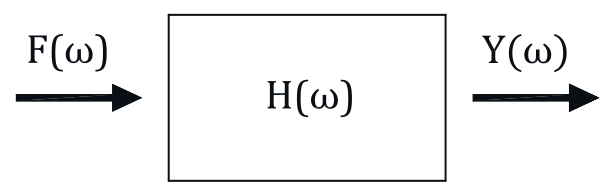

Slika 1. Shematski prikaz operativne modalne analize [1]

Na Slici $1,\{F(\omega)\}$ predstavlja pobudu na promatrani sustav, $[H(\omega)]$ funkciju frekventnog odgovora (Frequency Response Function, FRF), a $\{Y(\omega)\}$ odgovor sustava na nanesenu pobudu. Matematički se gore prikazana shematska veza može prikazati pomoću izraza:

$$
\{Y(\omega)\}=[H(\omega)] \cdot\{F(\omega)\}
$$

Matrica funkcija frekventnog odgovora $[H(\omega)]$ sadrži sve važne podatke o inercijalnim, elastičnim i disipirajućim svojstvima ispitnog objekta [2]:

$$
[H(\omega)]=\sum_{r=1}^{N_{m}} \frac{\left[R_{r}\right]}{i \omega-\lambda_{r}}+\frac{\left[R_{r}\right]^{*}}{i \omega-\lambda_{r}{ }^{*}}=\sum_{r=1}^{N_{m}} \frac{Q_{r} \cdot\left\{\phi_{r}\right\} \cdot\left\{\phi_{r}\right\}^{T}}{i \omega-\lambda_{r}}+\frac{Q^{r^{*}} \cdot\left\{\phi_{r}\right\}^{*} \cdot\left\{\phi_{r}\right\}^{* T}}{i \omega-\lambda_{r}{ }^{*}}
$$


U izrazu (2), Nm predstavlja broj modalnih oblika, $\left\{\phi_{\mathrm{r}}\right\}$ je vektor $r$-tog modalnog oblika, $\left[R_{\mathrm{r}}\right]$ rezidualna matrica iz koje se određuju modalni oblici, $Q_{\mathrm{r}}$ modalni skalirajući faktor, a $\lambda_{\mathrm{r}}$ pol r-tog modalnog oblika koji sadrži podatke o prigušenoj frekvenciji $f_{\mathrm{d}, \mathrm{r}}$ i koeficijentu prigušenja $\xi_{\mathrm{r}}$. Glavna prednost operativne modalne analize u odnosu na eksperimentalnu modalnu analizu je što pobudu $F(\omega)$ nije potrebno poznavati nego je dovoljno da se pobudom nanesenom na promatrani objekt mogu kvalitetno pobuditi svi modalni oblici koji se žele analizirati i pratiti. Postupci provedbe ispitivanja i analiza dobivenih rezultata koji su se koristili u ovom radu mogu se rastaviti na sljedeće faze [3]:

a) planiranje i provedba ispitivanja,

b) procesuiranje rezultata i „identifikacija“ modalnih parametara,

c) vrednovanje dobivenih rezultata.

\section{Laboratorijska dinamička ispitivanja}

Na Slici 2 prikazana je čelična greda pravokutnog šupljeg poprečnog presjeka $30 \times 50 \times 3,2 \mathrm{~mm}$ ukupne duljine $3,0 \mathrm{~m}$, oslonjena na dva drvena oslonca na način da osni razmak oslonaca iznosi 2,9 m. Njezin konstrukcijski sustav je slobodno oslonjena greda na dva nepokretna oslonca (Slika 2). Ispitivanja su provedena na nekoliko varijantnih sustava sa tri, četiri i šest akcelerometara koji su bili spojeni na jedan ili dva četverokanalna uređaja za prikupljanje signala (Slika 3).
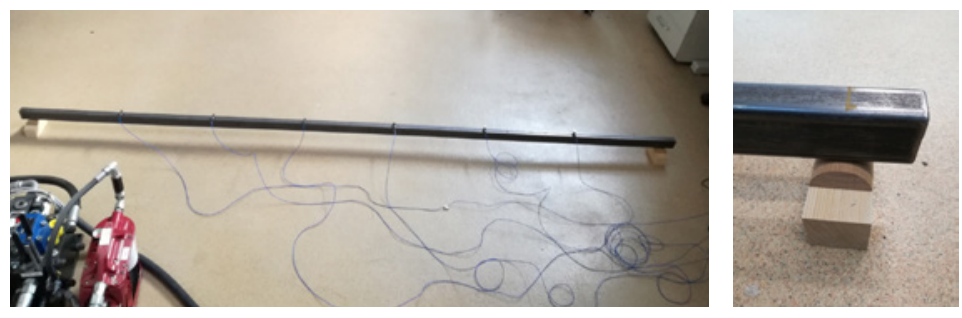

Slika 2. Postavka grede za ispitivanja (model D) i prikaz oslonca

Pri ispitivanju primijenjena je pobuda udarcem (impact) koja je ujedno i najčešće korištena tehnika pobude u modalnoj analizi. Vrijednosti modalnih parametara (frekvencije, modalni oblici, koeficijenti prigušenja) određeni su iz izmjerenih ubrzanja karakterističnih točaka primjenom metode „izvlačenja“ modalnih parametara u frekventnoj domeni [4]. Korišteni sustav za prikupljanje i obradu podataka ModalVIEW prije provedbe mjerenja zahtijeva kreiranje geometrijskog prikaza (modela) ispitivanog uzorka ili konstrukcije te zadavanje osnovnih smjernica softveru sukladno zahtjevima ispitivanja (karakteristike mjernih uređaja, frekvencija prikupljanja podataka, raspored i broj mjernih mjesta). 

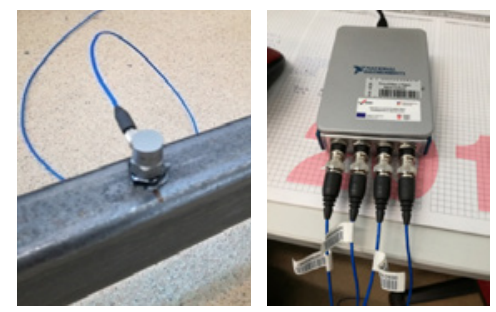

Slika 3. Pozicija akcelerometra na gredi (lijevo) i četverokanalni uređaj za prikupljanje podataka (desno)

Tablica 1. Različiti modeli ispitivanja grede [5]

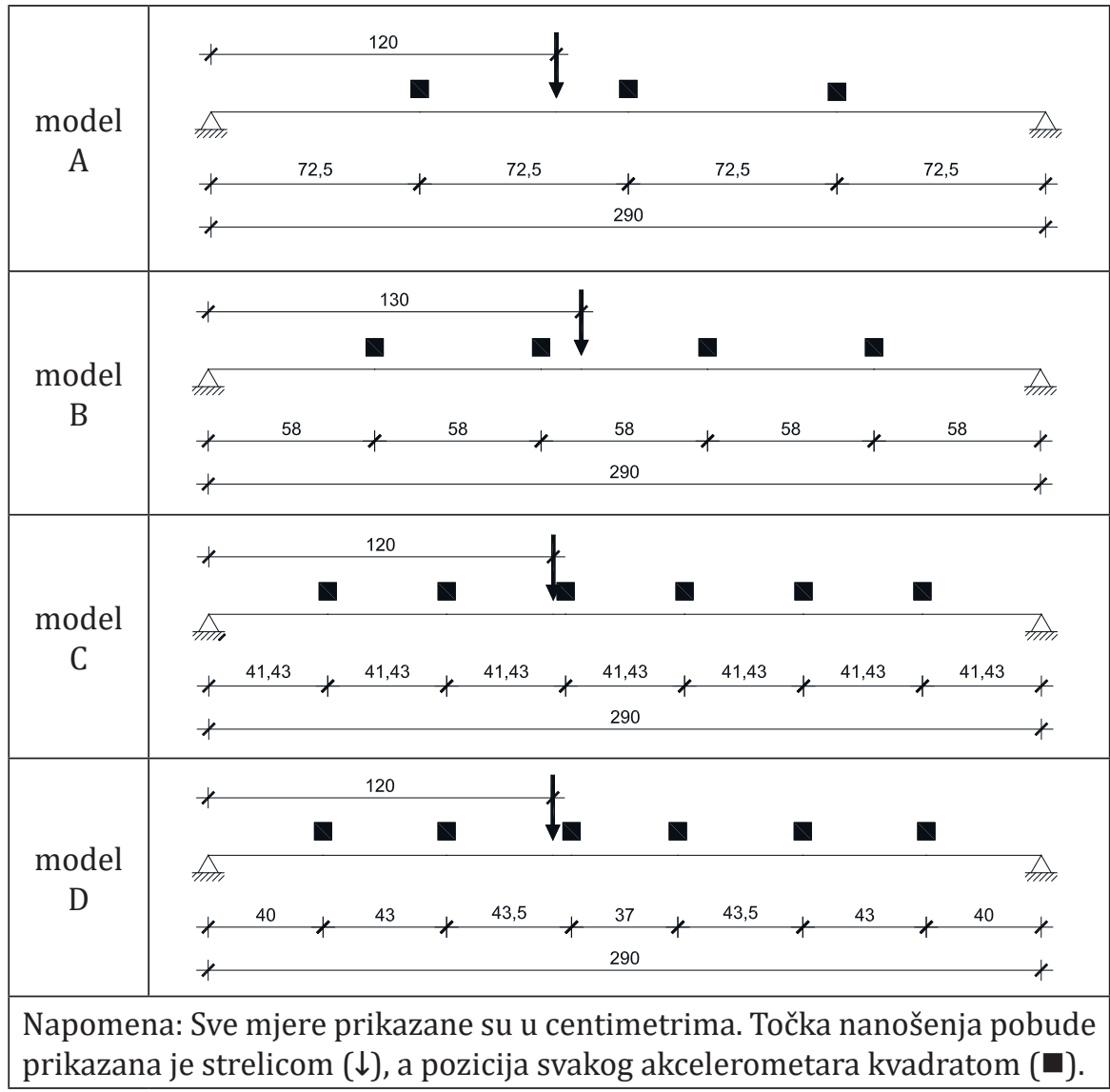

Geometrijski model grede opisuje se čvorovima i linijama pri čemu je svaki čvor određen oznakom, pozicijom i brojem koji označava broj stupnjeva slobode. Linija čini vezu između dva čvora kako bi geometrijski model prikazao gredu u stvarnom svijetu, a svaka linija određena je 
oznakom i indeksima čvorova koje povezuje. Svaki čvor na modelu može se definirati na kao mjerni, fiksni ili interpolirani. Oni čvorovi na geometrijskom modelu koji se podudaraju s mjernim točkama na fizičkom modelu, odnosno s točkama u kojima su postavljeni akcelerometri, definiraju se kao mjerni. Fiksni čvorovi su oni u kojima je kretanje onemogućeno (mjesta oslanjanja). Za zorniji prikaz modela mogu se dodati tzv. interpolirani čvorovi. Interpolirani čvorovi zadaju se između susjednih mjernih čvorova ili između mjernog i fiksnog čvora. U Tablici 1 prikazana su četiri modela ispitivanja grede $\mathrm{s}$ variranjem broja akcelerometara (tri akcelerometra - model A, četiri akcelerometra - model B i šest akcelerometara - modeli C i D).

\section{Rezultati laboratorijskih ispitivanja}

\subsection{Model A}

U Tablici 1 dan je shematski prikaz modela A koji se ispitivao za dva moguća slučaja. Prvi slučaj (A.I) je obuhvaćao ispitivanje bez zadanih interpolacijskih čvorova u geometrijskom prikazu definiranom $u$ ModalVIEWu, a drugi slučaj (A.II) je predstavljao ispitivanje s po jednim interpolacijskim čvorom između mjernih čvorova te mjernih čvorova i oslonaca. Dobivene vrijednosti frekvencija i koeficijenata prigušenja te prikazi modalnih oblika za slučaj bez interpolacijskih točaka i s interpolacijskim točkama prikazane su u Tablici 2.

Tablica 2. Model A - rezultati ispitivanja

\begin{tabular}{|c|c|c|c|c|}
\hline \multirow{2}{*}{$\begin{array}{c}\text { Modalni } \\
\text { oblik }\end{array}$} & \multicolumn{4}{|c|}{ Prikaz modalnih oblika, frekvencija i koeficijenata prigušenja } \\
\hline & \multicolumn{2}{|c|}{ A.I } & \multicolumn{2}{|c|}{ A.II } \\
\hline \multirow[t]{2}{*}{1} & & & & \\
\hline & $\mathrm{f}_{1}=16,76 \mathrm{~Hz}$ & $\zeta_{1}=0,1457 \%$ & $\mathrm{f}_{1}=16,76 \mathrm{~Hz}$ & $\zeta_{1}=0,2438 \%$ \\
\hline \multicolumn{5}{|l|}{2} \\
\hline & $\mathrm{f}_{2}=65,23 \mathrm{~Hz}$ & $\zeta_{2}=0,176 \%$ & $f_{2}=65,30 \mathrm{~Hz}$ & $\zeta_{2}=0,1861 \%$ \\
\hline \multicolumn{5}{|l|}{3} \\
\hline & $\mathrm{f}_{3}=134,90 \mathrm{~Hz}$ & $\zeta_{3}=0,5238 \%$ & $\mathrm{f}_{3}=135,30 \mathrm{~Hz}$ & $\zeta_{3}=0,4894 \%$ \\
\hline
\end{tabular}




\subsection{Model B}

Ispitivanje, prikupljanje i obrada podataka na modelu B provedeno je bez zadavanja interpolacijskih čvorova u ModalVIEWu jer se za model A pokazalo da se dodavanjem interpolacijskih čvorova smanjuje kvaliteta određenih modalnih oblika. U Tablici 3 dane su dobivene vrijednosti frekvencija i prigušenja te modalni oblici za model B.

Tablica 3. Model B - rezultati ispitivanja

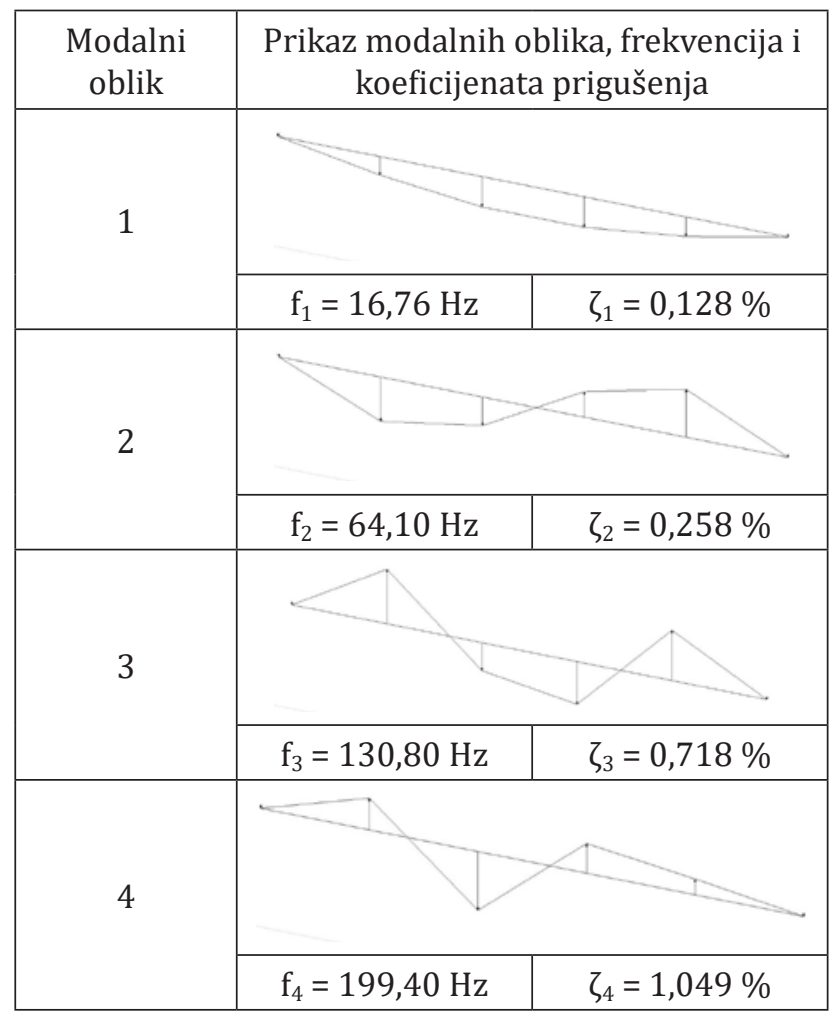

\subsection{Modeli C i D}

Ispitivanje provedeno na ispitnim konfiguracijama modela C i D provedeno je bez interpolacijskih čvorova u programskom paketu ModalVIEW, a dobivene vrijednosti modalnih frekvencija i koeficijenata prigušenja te prikazi modalnih oblika dani su u Tablici 4. Osnovna razlika između modela $\mathrm{C}$ i D je u rasporedu akcelerometara uzduž grede, kao što je i prikazano u Tablici 1. 
Tablica 4. Modeli C i D - rezultati ispitivanja

\begin{tabular}{|c|c|c|c|}
\hline \multirow{2}{*}{$\begin{array}{c}\text { Modalni } \\
\text { oblik }\end{array}$} & \multicolumn{3}{|c|}{ Prikaz modalnih oblika, frekvencija i koeficijenata prigušenja } \\
\hline & Model C & M & el D \\
\hline \multirow[t]{2}{*}{1} & & & \\
\hline & $\mathrm{f}_{1}=16,52 \mathrm{~Hz}$ & $f_{1}=16,53 \mathrm{~Hz}$ & $\zeta_{1}=0,3126 \%$ \\
\hline \multicolumn{4}{|l|}{2} \\
\hline & $\mathrm{f}_{2}=63,42 \mathrm{~Hz}$ & $\mathrm{f}_{2}=63,47 \mathrm{~Hz}$ & $\zeta_{2}=0,2578 \%$ \\
\hline \multicolumn{4}{|l|}{3} \\
\hline & $\mathrm{f}_{3}=129,80 \mathrm{~Hz}$ & $\mathrm{f}_{3}=129,90 \mathrm{~Hz}$ & $\zeta_{3}=0,6011 \%$ \\
\hline \multicolumn{4}{|l|}{4} \\
\hline & $\mathrm{f}_{4}=198,80 \mathrm{~Hz}$ & $\mathrm{f}_{4}=198,80 \mathrm{~Hz}$ & $\zeta_{4}=1,143 \%$ \\
\hline \multicolumn{4}{|l|}{5} \\
\hline & \begin{tabular}{l|l}
$\mathrm{f}_{5}=491,80 \mathrm{~Hz}$ & $\zeta_{5}=0,3744 \%$
\end{tabular} & $f_{5}=492,80 \mathrm{~Hz}$ & $\zeta_{5}=0,4188 \%$ \\
\hline \multirow[t]{2}{*}{6} & & & \\
\hline & $\mathrm{f}_{6}=656,80 \mathrm{~Hz}$ & $\mathrm{f}_{6}=657,0 \mathrm{~Hz}$ & $\zeta_{6}=0,2929 \%$ \\
\hline
\end{tabular}

\section{Usporedba rezultata ispitivanja i rezultata numeričkog proračuna}

Rezultati provedenih dinamičkih ispitivanja uspoređeni su s rezultatima dinamičke analize provedene na numeričkom modelu grede izrađenom u programsku paketu Staad.pro. Numeričkim dinamičkim proračunom moguće je izračunati frekvencije i modalne oblike, ali ne i modalno prigušenje pojedinih modalnih oblika nekog konstrukcijskog sustava. Slijedom navedenog usporedba je provedena za vrijednosti frekvencija i modalne oblike. 
Mrežom konačnih elemenata greda raspona 2,90 m je podijeljena na 60 štapnih elemenata, pri čemu je svaki element duljine 48,33 mm, a ležaji su definirani kao nepokretni. U modelu su zadana sljedeća svojstva materijala: modul elastičnosti $E=205000 \mathrm{~N} / \mathrm{mm}^{2}$, Poissonov koeficijent $v=0,3 \mathrm{i}$ obujamska težina $\gamma=77,0 \mathrm{kN} / \mathrm{m}^{3}$.

Pri određivanju frekvencija i modalnih oblika program Staad.pro ne uzima u obzir prigušenja. Takav numerički model je prihvatljiv za određivanje navedenih modalnih parametara uz uvjet da su koeficijenti prigušenja malih vrijednosti pa su frekvencije i modalni oblici prigušenih vibracija jednaki onima neprigušenih vibracija [6, 7]. Iz provedenih ispitivanja (Tablice 7 do 10) vidljivo je da su vrijednosti koeficijenata prigušenja u granicama od $0,128 \%$ do $1,143 \%$, što se smatra malim vrijednostima.

Na prethodno opisanom numeričkom modelu izračunate su frekvencije i modalni oblici vibriranja grede te su prikazani u Tablici 5. U nastavku su numerički dobivene frekvencije označene $s f_{n}$, izmjerene frekvencije bez interpolacijskih točaka $s f_{i}$, a frekvencije $s$ interpolacijskim točkama $f_{i, i n t}$.

Tablica 5. Numeričke vrijednosti i modalni oblici [5]

\begin{tabular}{|c|c|c|}
\hline $\begin{array}{c}\text { Modalni } \\
\text { oblik }\end{array}$ & $\begin{array}{c}\text { Frekvencija } \\
\mathrm{f}_{\mathrm{n}}(\mathrm{Hz})\end{array}$ & Prikaz modalnog oblika \\
\hline 1 & 16,80 & \\
\hline 2 & 67,05 & \\
\hline 3 & 150,36 & \\
\hline 4 & 266,06 & \\
\hline 5 & 590,74 & \\
\hline & & \\
\hline
\end{tabular}




\subsection{Model A}

Eksperimentalno dobivene frekvencije i numerički izračunate frekvencije za model A te razlike izmjerenih i numeričkih frekvencija prikazane su u Tablici 6, a u Tablici 7 grafički su dani prikazi modalnih oblika numerički izračunatih i konstruiranih na temelju izmjerenih podataka.

Tablica 6. Model A - usporedba frekvencija

\begin{tabular}{|c|c|c|c|c|c|}
\hline \multirow{2}{*}{$\begin{array}{c}\text { Modalni } \\
\text { oblik }\end{array}$} & \multicolumn{3}{|c|}{ Frekvencija $(\mathrm{Hz})$} & \multicolumn{2}{c|}{ Razlika frekvencija (\%) } \\
\cline { 2 - 6 } & $\mathrm{f}_{\mathrm{n}}$ & $\mathrm{f}_{\mathrm{i}}$ & $\mathrm{f}_{\mathrm{i}, \text { int }}$ & $\left(\mathrm{f}_{\mathrm{i}}-\mathrm{f}_{\mathrm{n}}\right) \cdot 100 / \mathrm{f}_{\mathrm{n}}$ & $\left(\mathrm{f}_{\mathrm{i}, \text { int }}-\mathrm{f}_{\mathrm{n}}\right) \cdot 100 / \mathrm{f}_{\mathrm{n}}$ \\
\hline 1 & 16,80 & 16,76 & 16,76 & 0,2 & 0,2 \\
\hline 2 & 67,05 & 65,23 & 65,30 & 2,7 & 2,6 \\
\hline 3 & 150,36 & 134,9 & 135,30 & 10,3 & 10,0 \\
\hline
\end{tabular}

Tablica 7. Model A - usporedba modalnih oblika

\begin{tabular}{|c|c|c|}
\hline $\begin{array}{c}\text { Modalni } \\
\text { oblik }\end{array}$ & Modalni oblici (eksperiment) & Modalni oblik (STAAD.Pro) \\
\hline \multirow{2}{*}{1} & A.I & \\
\cline { 2 - 3 } & A.II & \\
\hline \multirow{2}{*}{2} & A.I & \\
\cline { 2 - 3 } & A.II & \\
\hline \multirow{2}{*}{3} & A.I & \\
\hline & & \\
\hline
\end{tabular}


Izmjerene vlastite frekvencije za ispitivanje sa i bez interpolacijskih točaka za pojedine modalne oblike iste su ili slične vrijednosti. Odstupanja frekvencija dobivenih ispitivanjem $u$ odnosu na modalne frekvencije dobivene numeričkim proračunom iznose od 0,2 \% (za prvu modalnu frekvenciju) do 10,3 \% (za treću modalnu frekvenciju). Za prve dvije modalne frekvencije odstupanja izmjerenih i izračunatih vrijednosti su minimalne (do 2,7\%), dok je odstupanje izmjerenih modalnih frekvencija za treći modalni oblik oko $10 \%$.

Modalni oblici dobiveni ispitivanjem bez interpolacijskih čvorova vrlo dobro se podudaraju sa izračunatim modalnim oblicima dok modalni oblici dobiveni ispitivanjem s interpolacijskim čvorovima imaju lošije podudaranje s numerički dobivenim modalnim oblicima.

\subsection{Model B}

Usporedba eksperimentalno dobivenih modalnih oblika i vrijednosti frekvencija s numeričkim vrijednostima iz programskog paketa STAAD.Pro prikazana je u Tablici 8. Vrijednost $f_{\mathrm{i}}$ predstavlja eksperimentalno dobivenu modalnu frekvenciju, a $f_{\mathrm{n}, \mathrm{i}}$ numerički dobivenu frekvenciju u programskom paketu STAAD.Pro, pri čemu vrijedi da je $i=1$ do 4 .

Tablica 8. Model B - usporedba modalnih oblika i frekvencija

\begin{tabular}{|c|c|c|c|}
\hline \multirow{2}{*}{$\begin{array}{l}\text { Modalni } \\
\text { oblik }\end{array}$} & \multicolumn{2}{|c|}{ Modalni oblici i frekvencije } & \multirow{2}{*}{$\begin{array}{c}\text { Razlika } \\
\text { frekvencija (\%) }\end{array}$} \\
\hline & eksperimentalno & numerički & \\
\hline \multirow[t]{2}{*}{1} & & & \multirow[t]{2}{*}{0,24} \\
\hline & $f_{1}=16,76 \mathrm{~Hz}$ & $\mathrm{f}_{\mathrm{n}, 1}=16,80 \mathrm{~Hz}$ & \\
\hline \multirow[t]{2}{*}{2} & & & \multirow[t]{2}{*}{4,4} \\
\hline & $f_{2}=64,10 \mathrm{~Hz}$ & $\mathrm{f}_{\mathrm{n}, 2}=67,05 \mathrm{~Hz}$ & \\
\hline \multirow[t]{2}{*}{3} & & & \multirow[t]{2}{*}{13,01} \\
\hline & $\mathrm{f}_{3}=130,8 \mathrm{~Hz}$ & $\mathrm{f}_{\mathrm{n}, 3}=150,36 \mathrm{~Hz}$ & \\
\hline \multirow[t]{2}{*}{4} & & & \multirow[t]{2}{*}{25,05} \\
\hline & $\mathrm{f}_{4}=199,4 \mathrm{~Hz}$ & $\mathrm{f}_{\mathrm{n}, 4}=266,06 \mathrm{~Hz}$ & \\
\hline
\end{tabular}


Usporedbom eksperimentalno dobivenih i numeričkih modalnih oblika može se zaključiti da se prva tri modalna oblika vrlo dobro poklapaju, dok eksperimentalno određeni četvrti modalni oblik ne odgovara numerički određenom četvrtom modalnom obliku. Razlike numerički određenih i izmjerenih modalnih frekvencija za prva dva modalna oblika se razlikuju $0,24 \%$, odnosno $4,4 \%$. Treća modalna frekvencija se razlikuje za 13,01\% a četvrta za $25,5 \%$.

\subsection{Modeli C i D}

U Tablicama 9 i 10 prikazani su eksperimentalno dobiveni i numerički izračunati modalni oblici i frekvencije te njihove međusobne razlike na modelima C i D (prema Tablici 1 modeli s šest akcelerometara). Vrijednost $f_{\mathrm{i}}$ predstavlja eksperimentalno dobivenu modalnu frekvenciju, a $f_{\mathrm{n}, \mathrm{i}}$ numerički dobivenu frekvenciju u programskom paketu STAAD.Pro, pri čemu se $i$ kreće od 1 do 6.

Tablica 9. Model C - usporedba modalnih oblika i frekvencija

\begin{tabular}{|c|c|c|c|}
\hline \multirow{2}{*}{$\begin{array}{l}\text { Modalni } \\
\text { oblik }\end{array}$} & \multicolumn{2}{|c|}{ Modalni oblici i frekvencije } & \multirow{2}{*}{$\begin{array}{c}\text { Razlika } \\
\text { frekvencija (\%) }\end{array}$} \\
\hline & eksperimentalno & numerički & \\
\hline \multirow[t]{2}{*}{1} & & & \multirow[t]{2}{*}{1,67} \\
\hline & $\mathrm{f}_{1}=16,52 \mathrm{~Hz}$ & $\mathrm{f}_{\mathrm{n}, 1}=16,80 \mathrm{~Hz}$ & \\
\hline \multirow[t]{2}{*}{2} & & & \multirow[t]{2}{*}{5,41} \\
\hline & $f_{2}=63,42 \mathrm{~Hz}$ & $\mathrm{f}_{\mathrm{n}, 2}=67,05 \mathrm{~Hz}$ & \\
\hline \multirow[t]{2}{*}{3} & & & \multirow[t]{2}{*}{13,67} \\
\hline & $\mathrm{f}_{3}=129,90 \mathrm{~Hz}$ & $\mathrm{f}_{\mathrm{n}, 3}=150,36 \mathrm{~Hz}$ & \\
\hline \multirow[t]{2}{*}{4} & & & \multirow[t]{2}{*}{25,28} \\
\hline & $\mathrm{f}_{4}=198,80 \mathrm{~Hz}$ & $\mathrm{f}_{\mathrm{n}, 4}=266,06 \mathrm{~Hz}$ & \\
\hline
\end{tabular}




\begin{tabular}{|c|c|c|c|}
\hline \multirow{2}{*}{5} & & & \multirow{2}{*}{19,01} \\
\cline { 2 - 4 } & $\mathrm{f}_{5}=491,80 \mathrm{~Hz}$ & $\mathrm{f}_{\mathrm{n}, 5}=413,23 \mathrm{~Hz}$ & \\
\hline \multirow{2}{*}{6} & & & \multirow{2}{*}{11,18} \\
\cline { 2 - 3 } & & & \\
\hline
\end{tabular}

Tablica 10. Model D - usporedba modalnih oblika i frekvencija

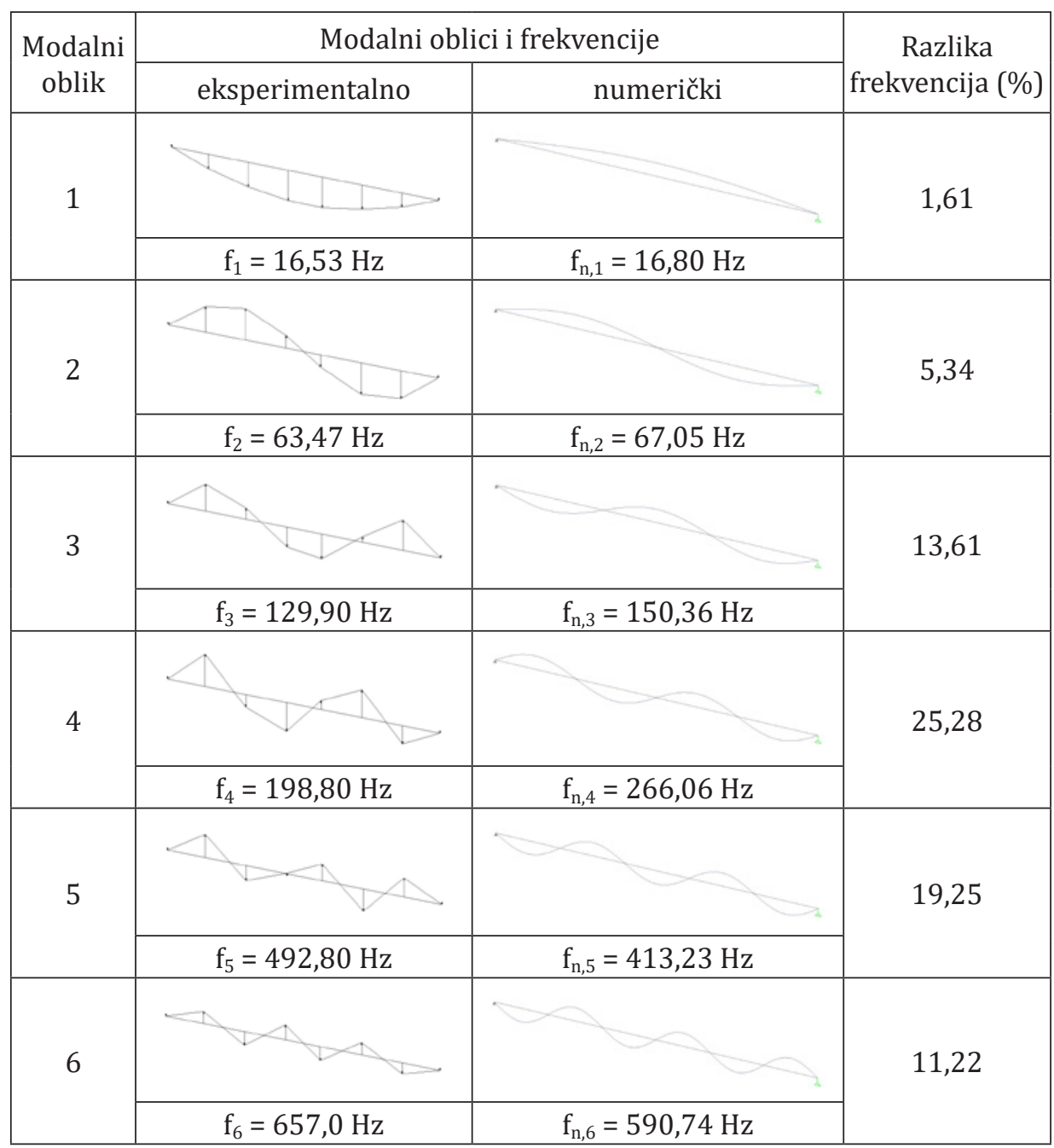


Rezultati prikazani u Tablicama 9 i 10 pokazuju da raspored akcelerometara za modele $\mathrm{C}$ i $\mathrm{D}$ daje zanemarive razlike u vrijednosti modalnih frekvencija za pojedini modalni oblik (do 0,2\%). Osim toga, eksperimentalno dobiveni treći, četvrti i peti modalni oblik za modele C i D nisu u potpunosti simetrični jer obuhvaćaju i moguće torzijske učinke.

Razlike između numeričkih modalnih frekvencija $f_{\mathrm{n}, \mathrm{i}}$ i eksperimentalno dobivenih frekvencija $f_{\mathrm{i}}$ za oba modela razlikuju se do $5,5 \%$ za prve dvije modalne frekvencije te više od $10 \%$ za preostale četiri modalna frekvencije. Također, razlika je najveća za četvrtu modalnu frekvenciju $(25,28 \%)$, nakon čega se razlika počinje smanjivati do šeste modalne frekvencije (oko $11 \%$ za oba modela).

\section{Rasprava i zaključak}

Rezultati modalnih frekvencija i modalnih oblika utvrđeni ispitivanjima te njihova usporedba s numeričkim dobivenim frekvencijama za modele $\mathrm{A}$ do D prikazani su u tablicama 11, 12 i 13.

Tablica 11. Pregled izmjerenih frekvencija po modelima

\begin{tabular}{|c|c|c|c|c|c|c|}
\hline \multirow{2}{*}{ Modeli } & \multicolumn{7}{|c|}{ Modalna frekvencija } \\
\cline { 2 - 7 } & 1. & 2. & 3. & 4. & 5. & 6. \\
\hline A.I & 16,76 & 65,23 & 134,90 & - & - & - \\
\hline A.II & 16,76 & 65,30 & 135,30 & - & - & - \\
\hline B & 16,76 & 64,10 & 130,80 & 199,40 & - & - \\
\hline C & 16,52 & 63,42 & 129,80 & 198,80 & 491,80 & 656,80 \\
\hline D & 16,53 & 63,47 & 129,90 & 198,80 & 492,80 & 657,00 \\
\hline $\begin{array}{c}\text { srednja } \\
\text { vrijednost }\end{array}$ & 16,67 & 64,30 & 132,14 & 199,00 & 492,30 & 656,90 \\
\hline $\begin{array}{c}\text { standardna } \\
\text { devijacija }\end{array}$ & 0,13 & 0,92 & 2,73 & 0,35 & 0,71 & 0,14 \\
\hline
\end{tabular}

Tablica 12. Razlike eksperimentalnih i numeričkih frekvencija

\begin{tabular}{|c|c|c|c|c|c|c|}
\hline \multirow{2}{*}{ Modeli } & \multicolumn{7}{|c|}{ Modalna frekvencija } \\
\cline { 2 - 7 } & 1. & 2. & 3. & 4. & 5. & 6. \\
\hline A.I & $0,2 \%$ & $2,7 \%$ & $10,3 \%$ & - & - & - \\
\hline A.II & $0,2 \%$ & $2,6 \%$ & $10,0 \%$ & - & - & - \\
\hline B & $0,24 \%$ & $4,4 \%$ & $13,01 \%$ & $25,05 \%$ & - & - \\
\hline C & $1,67 \%$ & $5,41 \%$ & $13,67 \%$ & $25,28 \%$ & $19,01 \%$ & $11,18 \%$ \\
\hline D & $1,61 \%$ & $5,34 \%$ & $13,61 \%$ & $25,28 \%$ & $19,25 \%$ & $11,22 \%$ \\
\hline
\end{tabular}


Tablica 13. Sličnost izmjerenih i numeričkih modalnih oblika

\begin{tabular}{|c|c|c|c|c|c|c|}
\hline \multirow{2}{*}{ Modeli } & \multicolumn{7}{|c|}{ modalni oblici } \\
\cline { 2 - 7 } & 1. & 2. & 3. & 4. & 5. & 6. \\
\hline A.I & $\mathrm{da}$ & $\mathrm{da}$ & $\mathrm{da}$ & - & - & - \\
\hline A.II & $\mathrm{da}$ & djelomično & $\mathrm{da}$ & - & - & - \\
\hline B & $\mathrm{da}$ & $\mathrm{da}$ & $\mathrm{da}$ & $\mathrm{ne}$ & - & - \\
\hline C & $\mathrm{da}$ & $\mathrm{da}$ & djelomično & djelomično & djelomično & $\mathrm{da}$ \\
\hline D & $\mathrm{da}$ & $\mathrm{da}$ & djelomično & djelomično & djelomično & $\mathrm{da}$ \\
\hline
\end{tabular}

Analizom i usporedbom rezultata dobivenih za modele A.I i A.II došlo se do zaključka da dodavanje određenog broja interpolacijskih točaka u modelu ne poboljšava prikaz eksperimentalno dobivenog modalnog oblika, već ga može i pogoršati. Rezultati dobiveni korištenjem modela A do D daju zadovoljavajuće vrijednosti modalnih frekvencija i zadovoljavajuće oblike za prva dva modalna oblika neovisno o tome koliko se akcelerometara koristi. Za sve ostale frekvencije razlika između eksperimentalnih i numeričkih rezultata prelazi $10 \%$. Modeli C i D ne daju međusobno skoro nikakve razlike u pogledu modalnih frekvencija i oblika iako im je raspored mjernih mjesta različit.

U teoriji je broj modalnih oblika koje je moguće konstruirati jednak broju stupnjeva slobode. Međutim, u praksi, broj kvalitetno određenih modalnih oblika na temelju eksperimentalnih podataka ovisi i o statičkom sustavu, vrsti oslonaca i načinu oslanjanja, krutosti i oblikovanju oslonaca te mogućim torzijskim učincima.

Kao što se može vidjeti iz prethodne usporedbe rezultata, oblici i vlastite frekvencije određeni su primjerenom točnošću samo za prva dva vlastita modalna oblika, što se može pripisati torzijskim učincima vibracija grede i neidealnim eksperimentalnim uvjetima oslanjanja (pobuđene vibracije drevnih oslonaca kod viših modalnih oblika).

Zahvala. Ovaj je članak rezultat rada u okviru projekta Razvoj istraživačke infrastrukture na Kampusu Sveučilišta u Rijeci (RC.2.2.060001) koji je sufinanciran iz Europskog fonda za regionalni razvoj (EFRR) i Ministarstva znanosti, obrazovanja i sporta $R H$. Članak je dio projekta Sveučilišta u Rijeci „Poboljšanje proračunskih modela za ocjenu stanja građevinskih konstrukcija". 


\section{Literatura}

[1] Rainieri, C., Fabbrocino, G. (2014). Operational Modal Analysis of Civil Engineering Structures. New York. Springer.

[2] Ewins, D.J. (2000). Modal Testing: Theory, Practice and Application. Baldock. Research studies press.

[3] Batel, M. (2002). Operational Modal Analysis - Another Way of Doing Modal Testing. S V Sound and Vibration. 36. 22-27.

[4] Brincker, R., Ventura, C. (2015). Introduction to Operational Modal Analysis. John Wiley and sons.

[5] Paparić, K. (2018). Laboratorijsko određivanje dinamičkih parametara na jednostavnim konstrukcijskim sustavima. Diplomski rad. Rijeka. Građevinski fakultet u Rijeci.

[6] Clough, R., Penzien, J. (1995). Dynamics of Structures. Berkeley. Computers and structures.

[7] M. Harris, Cyril \& G. Piersol, Allan. (2002). Harris' Shock and Vibration Handbook. New York. McGraw-Hill. 
